\title{
A Comparative Study of Psalms TCV and TEV Version from the Perspective of Dynamic Equivalence
}

\author{
Haiyan Gao \\ School of Foreign Languages, He Ze City, China
}

\begin{abstract}
The Bible, which contains the Old Testament and the New Testament, is called the cornerstone of western culture. The Psalms is a book included in the Old Testament and occupies an important position in the Bible. The importance of the Bible also prompts the development of numerous translation theories. Among many scholars who devote themselves to Bible translation survey, an American linguist, translation theorist Eugene Albert Nida proposed his systematic translation theory "Dynamic Equivalence" in the 1960s. It has influenced the Bible translation ever since then. Today's Chinese Version (TCV) is translated from Today's English Version (TEV) under the guidance of it during 1970s. Based on the guidance of dynamic equivalence, the TCV and TEV version of Psalms is compared and analyzed, aiming to prove the validation of the application of dynamic equivalence in bible translation and also point out some deficiencies.
\end{abstract}

Index Terms - dynamic equivalence, Psalms, TCV, TEV

\section{INTRODUCTION}

Eugene Albert Nida, as the Executive Secretary for Translations of the American Bible Society, has made unsurpassing achievements in the field of Bible translation. His most influential achievement lies in the contributions he made for the translation theory, which is still studied and used by many scholars not only focuses on Bible translation but also on the translation theory as a whole.

Among Nida's translation theories, his "Dynamic Equivalence" stresses that the best way for the people who have no pre-knowledge of the Bible to understand it is to place priority on effective communication while translating. In his opinion, the translation should be receptor-oriented. It is further divided into four aspects: equivalence on vocabulary, equivalence on syntax, equivalence on text, equivalence on style.

Under the guidance of Nida's Dynamic Equivalence, many Bible versions emerged during the 1960s and 1970s. Among which there is Today's English Version (TEV), also called Good News Bible (GNB), it is translated by Dr. Robert G. Bratcher in consultation with a committed appointed by the American Bible Society since 1957, and the translation is done according to the Dynamic Equivalence set forth by Eugene Albert Nida, in addition to being a Dynamic Equivalence version, it is also what some translation theorists call a "common language" version. Both of the names reflect that it is the language which is "common to the usage of both educated and uneducated" in any given language, so it is the level of language which most of the people can understand. Therefore, it has great popularity ever since its publication.

Today's Chinese Version (TCV) of the Bible was published in 1979, using Today's English Version as its original text, followed the "Dynamic Equivalence" of Nida.

This paper aims to compare and analyze the two versions under the guidance of Dynamic Equivalence, especially some case studies of the book Psalms, in order to prove the validation of the application of Dynamic Equivalence in Bible translation, and also point out some deficiencies.

\section{LITERATURE REVIEW}

China's Bible translation began in Tang dynasty and peaked in late Qing dynasty and early republication of China, even today, it is still pretty active. With the development of Bible translation in China and all over the world, the translation theory also develops.

In terms of translation theories of Bible translation, Nida's "Dynamic Equivalence" offers a principle for it. Nida sees translation as a communication event which moves from "source" to "receptor". In both original communication and translation, message must be received by the intended receptor. In 1975, Nida provided a clear definition of "Dynamic Equivalence" in his book The Theory and Practice of Translation: Dynamic equivalence is therefore to be defined in terms of the degree to which the receptors of the message in the receptor language respond to it in substantially the same manner as the receptors in the source language. (Nida, 1975).

In his opinion, translating was not to get something completely identical, but to reproduce "the closest natural equivalent to the source-language message" rather than "the conversation of the form of the utterance" in the receptor 
language. (Nida, 1975)

TEV and TCV are translated under the dynamic equivalence principle, in the following chapters this paper will analyze some cases chosen from the book Psalms to see the validation and also some deficiencies of the application of dynamic equivalence in Bible translation.

\section{Case Studies of Psalms from the Perspective of Dynamic Equivalence}

It is clear that the Psalms in TCV and TEV are translated under the guidance of dynamic equivalence. The guiding principles of TCV set by a group of Bible translating experts led by Eugene Albert Nida include almost every aspect of translation work. The main points will be introduced here:

(1) Target Language:

Dynamic equivalence is above formal equivalence.

The coherence of meaning is above that of words and sentences.

The spoken language is above the written language.

The language of people of secondary school level (people of 18 to 25 years old) is preferred.

The widely-used vernacular is above regional or classical language.

The translation must be understandable to both Christians and non-Christians.

(2) Style:

Try to reflect different styles of Biblical language according to the dynamic equivalence principle.

The translator is free to change the form of the source language in order to express its meaning faithfully.

(3) Idioms:

Chinese idioms can be used when acceptable, if misunderstandings would be roused.

The idioms in the source language should not be rendered literally, unless their precise meaning is maintained.

(4) Readability of the Target Language:

If the implication is relatively apparent, it should be made explicit.

Replace pronouns when their reference is ambiguous.

Use active voice if the initiator is not evident in the passive voice structure or maintain the passive structure but clarify the initiator.

To make the target language more smooth and understandable, the speaker of direct speech should be made clear, and direct and indirect speech can be exchanged.

Answers should be provided for rhetorical questions if there is no answer manifest or implied.

(5) Grammar:

Separate long and complicated sentences when necessary.

The unit of translation is the paragraph and the content of verses can be rearranged.

The textual basis and referential materials are also mentioned in the guiding principles: the general translation uses the third edition of the Today's English Version published in 1971 as the textual basis, and the evaluation group uses the Greek Bible published by the United Bible Society to check it. The translator also uses the New English Bible, the Jerusalem Bible, the Revised Standard Version and other commentaries to the Bible recommended by the United Bible Society as references. (Xu , 1983)

It is the dynamic equivalence principle acted as the guiding principle of TCV and TEV. This chapter will compare and analyze from four aspects, that is, equivalence on vocabulary, equivalence on syntax, equivalence on text and equivalence on style based on the principle of dynamic equivalence to see the validation of it in translation.

1. Equivalence on Vocabulary

The TCV and TEV translation of Psalms pay great attention to word choices. They use word free of ambiguity in translation, that is to say the word is always translated freely, not word-for-word, as long as the meaning in the target language is considered as precisely as in the original language.

1.1 Verb Choices

One of the most important differences between English and Chinese is the difference in verb choices. English is static while Chinese is dynamic. In Chinese, dynamic words are not only of common use but also more appealing. The technique of common occurrence converts different English word classes into Chinese verbs. It is clear that the TCV version uses more dynamic words than CUV (Chinese Unified Version) does, thus makes this version easier to be comprehended.

It is the dynamic equivalence principle acted as the guiding principle of TCV and TEV. This chapter will compare and analyze from four aspects, that is, equivalence on vocabulary, equivalence on syntax, equivalence on text and equivalence on style based on the principle of dynamic equivalence to see the validation of it in translation. For example:

Example 1:

$\mathrm{TCV}$ 他只爱慕上主的法律, 日夜默诵不倦。(《诗篇》1:2) 
TEV Instead, they find joy in obeying the law of the Lord, and they study it day and night. (Psalms 1:2)

Example 2:

$\mathrm{TCV}$ 上主啊, 求你不要发怒谴责我; 求你不要在烈怒下惩罚我! (《诗篇》6:1)

TEV Lord, don't be angry and rebuke me! Don't punish me in your anger! (Psalms 6:1)

Example 3:

$\mathrm{TCV}$ 上主啊, 你要审判万民。求你宣判我无辜, 因我无罪。（《诗篇》7:8）

TEV You are the judge of all people. Judge in my favor, O Lord; you know that I am innocent. (Psalms 7:8)

There are also some verbs used in TCV which do not appear in CUV

TABLE 1

VERBS PARTICULAR IN TCV

\begin{tabular}{|l|l|}
\hline Verses & Verbs can be found in TCV but not in CUV \\
\hline $1: 2$ & 默诵（meditates） \\
\hline $2: 7$ & 颁布（declare） \\
\hline $4: 3$ & 选召（chosen） 归属（for His own） \\
\hline $5: 3$ & 静候（wait） \\
\hline
\end{tabular}

\subsection{Avoid Theological Terms}

In order to help the people who have no religious background to understand the Bible easier, the TEV and TCV versions use no theological terms in Psalms, especially in TCV. The aim at biblical secularization is clearly seen. (Ren, 2007)

Example 4:

CUV 耶和华啊, 求你不要在怒中责备我, 也不要在烈怒中惩罚我。(《诗篇》6:1)

$\mathrm{TCV}$ 上主啊, 求你不要发怒谴责我; 求你不要在烈怒下惩罚我! (《诗篇》6:1)

TEV Lord, don't be angry and rebuke me! Don’t punish me in your anger! (Psalms 6:1)

Example 5:

CUV 主耶和华啊，你是我所盼望的，从我年幼，你是我所依靠的。(《诗篇》71:5)

$\mathrm{TCV}$ 上主啊，你是我的希望; 我从年幼时就信赖你。（《诗篇》71:5）

TEV Sovereign Lord, I put my hope in you; I have trusted in you since I was young. (Psalms 71:5)

The names like Jehovah are substituted with other expressions in TEV and TCV, which helps the non-Christians to read, such examples can be found easily in other places of the Bible too. There are hundreds of names for God, it is even hard for Christians to understand and remember all the names, not to say the non-Christians. Basing on Nida's dynamic equivalence, TEV and TCV have avoided theological terms.

\section{Equivalence on Syntax}

Syntax is the study of how words are combined with others to form sentences and in what order. This following part will analyze from the addition of sentences and division of sentences.

\subsection{Addition of Sentences}

Addition is also called amplification of words. It means to add necessary words while translating on the condition of not destroying the accuracy of the translation or affect the comprehension of original text.

As a matter of fact, addition is used in order to realize the "faithful representation" of the meaning of the original text. English and Chinese belong to two different language systems and have different historical and culture backgrounds. Besides, many ideas, idiomatic expressions and shorthand words that are well understood in the country of their origin can hardly make sense to people abroad. (Xu , 2007)

Example 6:

CUV 你必用铁杖打破他们, 你必将他们如窑匠的瓦器摔碎。（《诗篇》2:9)

$\mathrm{TCV}$ 你要用铁腕统治他们; 你要粉碎他们, 像粉碎瓦器一样。(《诗篇》2:9)

TEV You will break them with an iron rod; you will shatter them in pieces like a clay pot. (Psalms 2:9)

\subsection{Division of Sentences}

Division means when an English sentence is too long or too complicated to understand, then the English sentence is divided into two or several sentences according to the sentence groups in the original text. This is a distinct characteristic in TCV and TEV versions.

Example 7:

CUV 他必用自己的翎毛遮蔽你，你要投靠在他的翅膀底下。他的诚实是大小的盾牌。(《诗篇》91:4)

TCV 他要用翅膀庇护你; 在他的看顾下你一定安全; 他的信实要保护你。（《诗篇》91:4）

TEV He will cover you with his wings; you will be safe in his care; his faithfulness will protect and defend you.

(Psalms 91:4)

Example 8:

CUV 你们要赞美耶和华! 你们要赞美耶和华的名！耶和华的仆人站在耶和华殿中, 站在我们 神殿院中的, 你们要赞美他! (《诗篇》135:1)

TCV 要赞美上主！上主的仆人哪，要颂赞; 你们要颂赞上主的名。（《诗篇》135:1） 
TEV Praise the Lord! Praise His name, you servants of the Lord. (Psalms 135:1)

TCV and TEV use two to three times more short sentences than CUV version, which makes the version a lot easier for people to understand. Short sentences make the text easier to understand. It is also an application of dynamic equivalence in translation.

\section{Equivalence on Text}

Although sentence equivalence is important, the equivalence on text is more important because as a whole text conveys the meaning and culture background behind the original text. Language is within its culture and influences its culture at the same time, so the whole text should be taken into consideration while translating. The Bible is also a book with a long history which has valuable culture legacy. This following part will discuss the equivalence on text from the coherence of text and cultural interpreting.

\subsection{Coherence of Text}

Example 9:

CUV 都因仇敌的声音，恶人的欺压，因为他们将罪蒘加在我身上，发怒气逼迫我。（《诗篇》55:3）

TCV 仇敌的恐吓, 恶人的逼迫，都使我烦乱不已! 他们把灾难加给我; 他们向我发怒，憎恨我。（《诗篇》55:3）

TEV I am terrified by the threats of my enemies, crushed by the oppression of the wicked. They bring trouble on me; they are angry with me and hate me. (Psalms 55:3)

The TCV and TEV versions both use the same subject for two short sentences, which enables readers, especially readers who have relatively low education to understand the meaning with ease.

\subsection{Cultural Interpreting}

Due to the different culture backgrounds, patterns of expression and different language systems, there will surely be some culture obstacles in the Bible translation and absolute equivalence is impossible to be achieved. If the original text is translated literally, it will be difficult for the readers to appreciate it accurately. So culture interpreting should be an important factor to be taken into account while translating to achieve text equivalence.

One good example may be the proverbs and idioms in the language, the meaning of them can never be the same as each simple word added together. The perfect solution is that the translator can find the exact correspondence in the target language, but if there is not one, the translator should translate it into an expression with similar meaning with the original idiom or proverb. For example: one verse in TEV version says "You will make them burn with shame and the Lord will reward you. (Proverbs 25:22)”, in CUV version it says “因为你这样行, 就是把炭火堆在他的头上; 耶和华 也必赏赐你。(《筬言》25:22)”, which doesn’t help the reader to understand that the meaning of the original phrase, however, the TCV version says “你这样做, 会使他脸红耳赤, 羞惭交加, 上主也要报答你。(《筬言》25: 22)”, which is a great help to the readers with no background knowledge of the original text.

Another example is the festivals which always reflect cultural and historical color; this is better reflected in other books of the Bible such as Leviticus.

In a word, equivalence of text is more complicated because passage is a whole and it contains cultural factors. But dynamic equivalence is still a useful and successful guiding principle for translation.

\section{Equivalence on Style}

The last part of this chapter is going to focus on equivalence on style. Style as a noun means a way of using words or spellings that is considered correct. Here this paper will focus on the preference of modern Chinese words in TCV version.

The CUV version of Chinese Bible can be said to be the most popular version in Chinese community, which has been printed numerous times after its publication. However, it is translated in 1920s, thus some words and expressions seem to be outdated and cannot be easily understood sometimes by the people today. But TCV uses words and expressions of today's Chinese. For example, in John3:10, the CUV uses 先生 (a master) while the TCV uses 教师 (a great teacher), and in Luke14:20, the CUV uses 娶了妻 (have married his wife) while the TCV it becomes 结婚 (get married).

\section{LiMitATIONS AND SUGGESTIONS}

Although dynamic equivalence plays an important part in translation, especially Bible translation, it is not easy to realize it all the time and it is hardly impossible to realize a hundred percent equivalence to the original text all the time. The differences in culture background, ways of expression, language structures, and the concepts in the source language may be hard to find equivalence or have different meanings in the target language. TCV and TEV are undoubtedly great accomplishments in Bible translation. However, nothing can be perfect, so do dynamic equivalence and the two versions.

The essence of translation, according to Nida, is dynamic equivalence rather than formal correspondence. He puts key emphasis on reader's acceptance of the translated text. Although this seems to show esteem to readers, it neglects the writer and the original text. Dynamic equivalence lays more stress on the readability of the Bible translation, which inevitably leads to the simplification and even the loss of literature of the original text. With the rapid growth of culture communication across countries, adopting notes to convey culture seems to be a way out for dynamic equivalence.

TCV and TEV are mainly translated on the basis of Nida's dynamic equivalence. In order to obtain the first-hand material about how people accept these two versions, a questionnaire is designed for both Christians and non-Christians. 
The purpose of the questionnaire is to see how much people know about Bible versions and also their attitudes towards different translations. 50 Christians and 50 non-Christians took the questionnaire during April, 2011.

TABLE 2

ANALYSIS OF THE QUESTIONNAIRE

\begin{tabular}{|l|l|l|l|l|}
\hline & $\begin{array}{l}\text { Prefer TCV(现代中文译 } \\
\text { 本) }\end{array}$ & Prefer CUV(和合本) & $\begin{array}{l}\text { TEV is easier to KJV is easier to } \\
\text { understand }\end{array}$ & $\begin{array}{l}\text { KJ understand } \\
\text { Christians }\end{array}$ \\
\hline Non-Christians & 40 & 45 & 46 & 4 \\
\hline
\end{tabular}

The analysis shows that firstly, although the CUV still enjoys quite popularity among Christians, most of the non-Christians showed strong preference for TCV. Secondly, the TEV enjoys a better acceptance among both Christians and non-Christians, which is in accordance of the author's predication and the translator's purpose. Moreover, it supports the validation of dynamic equivalence in Bible translation.

TEV is an easier and more updated version so undoubtedly it enjoys preference among both Christians and non-Christians; this is also what the dynamic equivalence wants to bring out. As for TCV version, it is also showing the potential of widely acceptance. However, the CUV still enjoys the preference among Christians. One reason is that it is a traditional version widely used in churches and believers ever since its publication so people get used to it, the other reason may expose the fact that TCV still has some defects. For example, some words and expressions may be outdated today and even bear characteristics of feudalism. And some renderings whose original text may appear not in consistent with its meaning in TCV.

TCV and TEV are later versions in Bible translation, as analyzed above, some better renderings still need to be further revised. As an outstanding guiding principle, dynamic equivalence can also be applied successfully in later translation practices.

\section{CONCLusion}

Nida's dynamic equivalence is based on a solid foundation of information theory, communication theory, and semiotics. Nida also holds the opinion that "Before translating a text, a translator must often unpack the condensed academic language, and this cannot be done without a knowledge of language structures and of the culture". (Nida, 1993)

This helped to show the sociolinguistics-oriented root in Nida's theory.

The dynamic equivalence helped to bring birth to the more natural and easier to be understood Bible versions such as Today's Chinese Version and Today's English Version, which both became worldwide accepted versions and easier for people who has no religious background to appreciate. The popularity of these two versions also proves that the application of Nida's dynamic equivalence in Bible translating is a success.

However, no translation theory can be considered as a universal principle which can be applied to all kinds of texts. Dynamic equivalence also has its own defects and limitations, and a hundred percent equivalence is impossible to be realized. But the goal of the Bible translation is to convey God's message to His believers. So it is more practical and more important to pursue the dynamic equivalence in meaning so that more people can have easier access to its meaning. Besides, the application of dynamic equivalence is proved to be valid and successful. So there is more than enough reason to say that dynamic equivalence still has a profound meaning in guiding Bible translation.

Just like no translation theory is universal, no Bible translation needs to be regarded to be perfect forever. But generally speaking, the TCV and TEV versions which are both translated under the guidance of dynamic equivalence can be regarded as a success in translation field. Nida's dynamic equivalence theory will also occupy an important guiding status in translation field.

\section{REFERENCES}

[1] Eugene Albert Nida. (1975). Language, Structure and Translation: Essays by Eugene A. Nida. Stanford: Stanford University Press.

[2] Xu Mushi. (1983). Bible and Translation Versions. Hongkong: literary arts Publication Company.

[3] Ren Dongsheng. (2007). Study on Bible Translation Culture. Wuhan: Hubei education press.

[4] Xu Jianping. (2007). A Practical Course of English-Chinese and Chinese-English Translation. Beijing: Tsinghua university press.

[5] Eugene Albert Nida. (1993). Language, Culture and Translating. Shanghai: Shanghai Foreign Language Education Press.

Haiyan Gao was born in Linyi, China in 1983. She received her Master degree in English language and Literature from Liaocheng University, China in 2009.

She is currently an instructor in the School of Foreign Languages, Heze University, China. Her research interests include English language and literature, text translation, and English teaching. 